\title{
Effect of Led Drying on Drying Behavior of Prunus domestica L. Fruit
}

\author{
Mithat Akgün ${ }^{1 *}$, Levent Kandemir², Burhan Öztürk \\ ${ }^{1}$ Program of Machine and Metal Technologies, Technical Sciences Vocational School, Ordu University, Ordu, TURKEY. \\ 2Department of Renewable Energy, Graduate College of Science, Ordu University, Ordu, TURKEY. \\ ${ }^{3}$ Department of Horticulture, Faculty of Agriculture, Ordu University, Ordu, TURKEY.
}

\begin{abstract}
Background: Energy efficiency is becoming increasingly important in storing foods preserving their own characteristics and fruits and vegetables by drying in terms of selflife as well. Objectives: Since the Black Sea Region of Turkey is rainy and extremely humid during the harvest period of fruits and vegetables, the region is not suitable for natural drying of fruits and vegetables. For this reason, additional energy is needed for drying in the region. The Prunus domestica L. fruit that grown naturally in the Black Sea Region was dried using LED technology in a short time with minimum energy and preserving food properties, along with traditional methods. Methods: The fruits were dried at fixed lumen (10000 lumen) using the LED's of three different color temperatures (3000 K, $4000 \mathrm{~K}$ and $6500 \mathrm{~K}$ ), along with traditional (sun drying) and conventional (using electrical heater) drying. In addition, the effects of drying conditions on watersoluble dry matter, vitamin $\mathrm{C}$, total phenolic, total flavonoid and total antioxidant (FRAP, DPPH) properties were investigated. Results: Time-dependent drying curves of Prunus domestica L. at five different drying conditions and time-dependent changes of the dryer temperature with LED drying were obtained. Conclusion: The drying time with 3 different LED temperatures was found to be shorter than that of the drying time of sun drying and electric heater. It was concluded that, energy efficiency was better in LED drying than those of conventional methods.
\end{abstract}

Key word: Food drying, Sun drying, LED technology, Drying curve.

\section{INTRODUCTION}

Food drying is the process of lowering nourishment, which allows food to be stored for long periods of time while preserving its properties. The drying process is carried out naturally or mechanically, depending on the developing technologies. Some agricultural products (wheat, lentils, beans) can be dried naturally (by branch or by solar energy), but mechanization is needed for drying most agricultural products.

Drying kinetic of a product is to determine the time-dependent moisture loss from the product, depending on the moisture amount, temperature and flow rate of the drying air. Besides these parameters, the genus, geometry, size and quantity of the product also play an important role in dryer design and optimization.

To meet the needs of the growing world population in a short time, with the least amount of energy, very different theoretical and experimental studies have been carried out to determine dryness of the products, dry the food and develop drying techniques and its mechanizations.

In drying process, the first theoretical model for the heat and mass transfer of damp materials was proposed by Luikov in $1973 .{ }^{1}$ Hawlader et al. determined drying characteristics of tomato by performing some experiments at various drying fluid velocities and at different atmospheric conditions. ${ }^{2}$
Submission Date: 30-08-2016; Revision Date: 17-11-2016; Accepted Date: 23-11-2016

DOI: 10.5530/ijper.52.4s.85 Correspondence: Mithat Akgün,

Program of Machine and Metal Technologies, Technical Sciences Vocational School, Ordu University, Ordu, TURKEY.

E-mail: mithatakgun@gmail. com

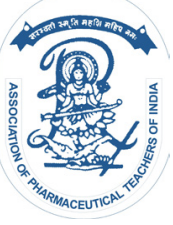

www.ijper.org 
Çevik and Bilişli, investigating the artificial drying characteristics of nine types of plums in cabin dryers; they found Tuteu, Timpuriu and Prune among slice-dried plum varieties and Krikon Damson and Giant among whole-dried plum varieties to be suitable for drying. ${ }^{3}$

Krokida et al. examined the effect of drying weather conditions (speed, temperature and humidity) and the product characteristic dimension on drying kinetic. The study was conducted at two different temperatures of the air $\left(30^{\circ} \mathrm{C}\right.$ and $\left.70^{\circ} \mathrm{C}\right)$. It was found that the drying constants increased slightly by drying temperature, while the equilibrium moisture decreased with drying temperature. ${ }^{4}$

Karaarslan dried the Japanese persimmon until its moisture content decreased down to $15 \%$ at 5 different power levels of $180,360,540,720$ and $900 \mathrm{~W}$. It was observed that the fastest drying was at $900 \mathrm{~W}^{5}$

Mehta et al. examined the effects of phytochemical, antioxidant and antibacterial activity dry plum (Prunus domestica) on health. They indicated that Prunus domestica was an energy source with low fat content with its protein and dietary fiber contents were 3.80\% and $2.79 \%$, respectively. ${ }^{6}$

In the Black Sea Region of Turkey where the work is done, crops (fruit and vegetables) are harvested during a rainy harvest season. It is necessary to dry agricultural products with additional energy because of rains and excessive amount of air moisture. So, it is important to determine drying parameters according to agricultural crops and to determine technology that will enable drying of large quantities of crops in a short time with low energy cost. Prunus domestica L. fruits were used in this experimental study. The fruits used in the study were selected from naturally grown plums in the region.

In this study, three types of LED color temperatures were selected, which are modeled by drying on the sun and close to the solar color temperature. The fruits were dried at fixed lumen (10.000 lümen) using the LED's of three different color temperatures $(3000 \mathrm{~K}, 4000 \mathrm{~K}$ and $6500 \mathrm{~K}$ ), along with traditional (sun drying) and conventional (using electrical heater) drying for comparison of drying methods.

\section{MATERIAL AND METHODS}

In this study, plums were dried as cut in half (seedless) and as a whole kernel. However, since the drying times of all plums were very long, and fruit decaying occurred in time in sun drying in the region, full crop drying values have not been given solely for drying with LEDs. Drying with oven electric heater; to compare with the other drying conditions, the oven temperature is kept constant at $43^{\circ} \mathrm{C}$ and mass transfer with natural circulating air was performed in the oven. The mass loss of plums was measured as time dependent. In sun drying, the product was kept on a cotton cover and the mass loss of the plums was measured by time.

In LED drying operation, LEDs with three different color temperatures $(3000 \mathrm{~K}, 4000 \mathrm{~K}$ and $6500 \mathrm{~K})$ were mounted on the dryer cabinet in such a way that the lumens were constant. The distance between the LEDs and the product was set to $10 \mathrm{~cm}$. The energy obtained from the LED was supplied to the product by convection and radiation. Oven temperature and product temperature were measured with thermoeleman and temperatures were recorded according to time with data card. The photograph of the drying cabin with LED was given in Figure 1. In addition, the mass loss of the melt was measured in time.

The effects of drying conditions on water-soluble dry matter, vitamin $\mathrm{C}$, total phenolic, total flavonoid and total antioxidant (FRAP, DPPH) properties were investigated. Prunus domestica fruit's humidity was measured by infrared method and the initial humidity was \%78-81. Fruits with a diameter range of $20-28 \mathrm{~mm}$ were used in the study.

\section{RESULTS AND DISCUSSION}

In the drying cabinet with LED, the temperature was $30^{\circ} \mathrm{C}$ at the beginning of the drying, the inside temperature of the cabin increased during the drying and it was found that the cabin internal temperature remained constant at about $46^{\circ} \mathrm{C}$ for three different LEDs. In the drying carried out at three different LED color temperatures, the two-part seedless plums dried fast, but it did not seem to be a proper drying process in terms of both time and energy efficiency, due to the drying period of the whole plums was long (Figure 2).

As shown in Figure 3, the drying periods of LEDs with three different color temperatures $(3000 \mathrm{~K}, 4000 \mathrm{~K}$, $6500 \mathrm{~K}$ ) for about $28 \%$ dry matter were $41 \%, 25 \%, 35 \%$ shorter than that of electric heater $\left(\mathrm{T}=43^{\circ} \mathrm{C}\right.$ constant $)$ and $64 \%, 55 \%$ and $60.6 \%$ shorter than sun drying, respectively.

It was found that, LED drying with a color temperature of $3000 \mathrm{~K}$ (yellow color) was occurred in a lesser time $(20 \%, 10 \%)$ those of LEDs with a color temperature of $4000 \mathrm{~K}$ (warm white colors) and $6500 \mathrm{~K}$ (cold white colors). In sun drying, some fluctuations were observed in the drying speed depending on day and night changes. The SSC of dried plum fruits in sun was significantly higher than those of other fruit samples (Table 1). As compared to fresh plum fruits, higher $\mathrm{pH}$ was observed 


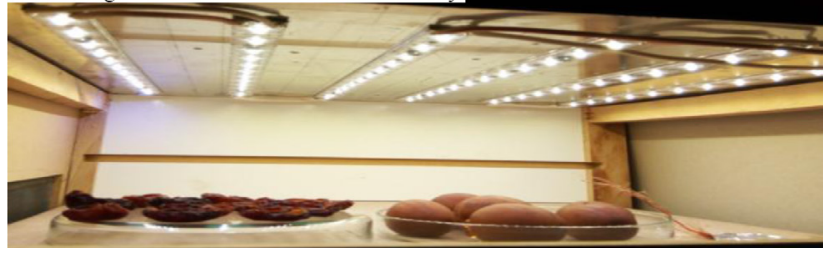

Figure 1: Photo of the drying cabin with LED. in dried plum in oven and LED light for $3000 \mathrm{~K}$. The titratable acidity content of fresh plum fruits was lower than that of dried plum fruits. Both LED and sun dried plum fruits had significantly higher vitamin $\mathrm{C}$ content than the fresh plum fruits and dried plum fruits in oven. As shown in Table 2, the higher $\mathrm{L}^{*}$ and $\mathrm{a}^{*}$ values were obtained from fresh plum fruits, whereas the higher $\mathrm{b}^{*}$ and chroma values were determined from dried plum in LED light for $4000 \mathrm{~K}$ The hue angle values of dried plum fruits in LED were significantly higher than other fruit samples.
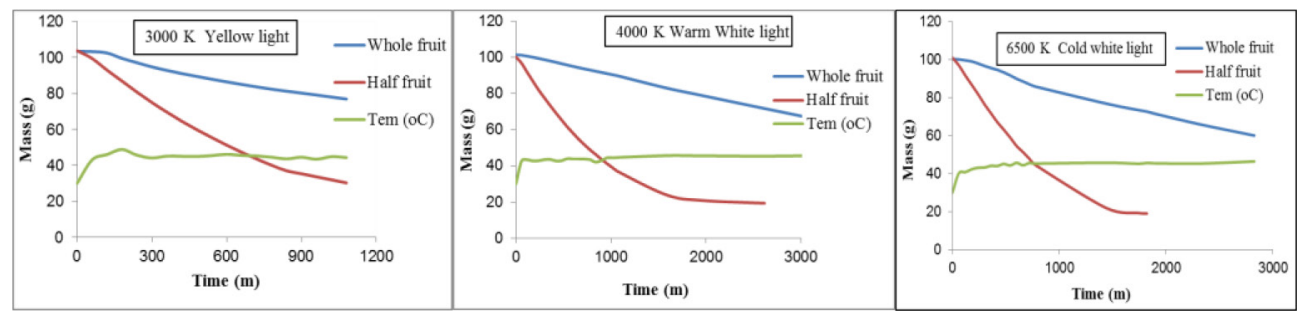

Figure 2: Mass- time diagrams of Prunus domestica L.

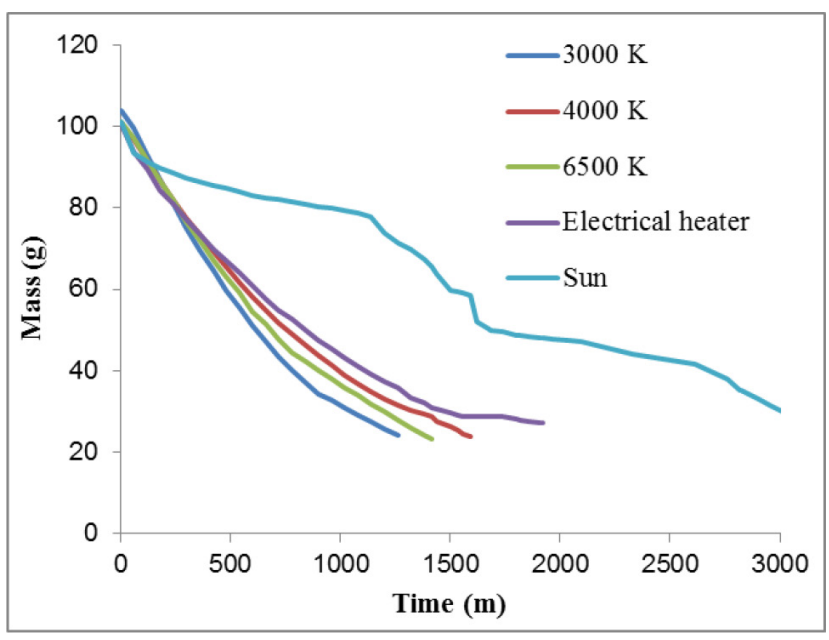

Figure 3: Mass- time diagram of Prunus domestica L. (half fruit).

\begin{tabular}{|c|c|c|c|c|}
\hline \multirow[b]{2}{*}{ Samples } & SSC & pH & $\begin{array}{c}\text { Titratable } \\
\text { acidity }\end{array}$ & $\begin{array}{l}\text { Vitamin } \\
\text { C }\end{array}$ \\
\hline & (\%) & & $\begin{array}{l}\text { (g malic acid } \\
100 \mathrm{~g}^{-1} \text { ) }\end{array}$ & $\left(\mathrm{mg} \mathrm{kg}^{-1}\right)$ \\
\hline Fresh plum & $\begin{array}{c}4.90 \\
d^{*}\end{array}$ & $\begin{array}{c}3.76 \\
b\end{array}$ & $0.39 \mathrm{~d}$ & $48 c$ \\
\hline Dried Plum in Sun & $\begin{array}{c}11.50 \\
a\end{array}$ & $\begin{array}{c}3.75 \\
b\end{array}$ & $0.71 \mathrm{a}$ & $116 \mathrm{~b}$ \\
\hline $\begin{array}{l}\text { Dried Plum in Oven } \\
\text { (Electrical heater) }\end{array}$ & $\begin{array}{c}7.30 \\
\mathrm{C}\end{array}$ & $\begin{array}{c}4.70 \\
\mathrm{a}\end{array}$ & $0.51 \mathrm{~b}$ & $53 \mathrm{c}$ \\
\hline $\begin{array}{l}\text { Dried Plum in LED } \\
\text { light for } 3000 \mathrm{~K}\end{array}$ & $\begin{array}{c}8.90 \\
b\end{array}$ & $\begin{array}{c}4.71 \\
\mathrm{a}\end{array}$ & $0.48 \mathrm{~b}$ & $112 \mathrm{~b}$ \\
\hline $\begin{array}{l}\text { Dried Plum in LED } \\
\text { light for } 4000 \mathrm{~K}\end{array}$ & $\begin{array}{c}9.30 \\
b\end{array}$ & $\begin{array}{c}3.78 \\
b\end{array}$ & $0.47 \mathrm{~b}$ & $115 b$ \\
\hline $\begin{array}{l}\text { Dried Plum in LED } \\
\text { light for } 6500 \mathrm{~K}\end{array}$ & $\begin{array}{c}9.00 \\
b\end{array}$ & $\begin{array}{c}3.79 \\
b\end{array}$ & $0.43 \mathrm{c}$ & $129 a$ \\
\hline
\end{tabular}

*: Means in columns with the same letter do not differ according to Tukey's test at $\mathrm{P}<0.05$.

\begin{tabular}{|c|c|c|c|c|c|}
\hline Samples & $L^{*}$ & $a^{*}$ & $\mathbf{b}^{*}$ & Chroma & Hue angle \\
\hline Fresh plum & $32.42 \mathrm{a}$ & $13.48 \mathrm{a}$ & $8.55 \mathrm{c}$ & $16.11 \mathrm{~b}$ & $31.86 \mathrm{c}$ \\
\hline Dried Plum in Sun & $22.83 b$ & $7.79 \mathrm{c}$ & $6.21 \mathrm{~d}$ & $9.96 \mathrm{c}$ & $38.53 b$ \\
\hline Dried Plum in Oven (Electrical heater) & $19.19 \mathrm{c}$ & $8.75 \mathrm{c}$ & $8.14 \mathrm{c}$ & $10.95 \mathrm{c}$ & $40.93 \mathrm{~b}$ \\
\hline Dried Plum in LED light for $3000 \mathrm{~K}$ & $24.40 \mathrm{~b}$ & $11.25 b$ & $11.40 \mathrm{~b}$ & $16.04 \mathrm{~b}$ & 45.49 a \\
\hline Dried Plum in LED light for $4000 \mathrm{~K}$ & $24.21 \mathrm{~b}$ & $13.34 \mathrm{a}$ & $14.10 \mathrm{a}$ & $19.51 \mathrm{a}$ & $46.43 \mathrm{a}$ \\
\hline Dried Plum in LED light for $6500 \mathrm{~K}$ & $23.36 \mathrm{~b}$ & $11.23 b$ & $12.65 \mathrm{~b}$ & $16.92 \mathrm{~b}$ & $47.38 \mathrm{a}$ \\
\hline
\end{tabular}

Means in columns with the same letter do not differ according to Tukey's test at $P<0.05$. 


\section{CONCLUSION}

In plum drying, drying systems with LEDs have been determined to be superior in terms of time and energy efficiency compared to electric heating systems and solar drying. For LED selection (in fixed lumen), yellow LED $(3000 \mathrm{~K})$ is more efficient than white LED $(4000 \mathrm{~K}$ and $6500 \mathrm{~K}$ ) in terms of drying time. Drying as whole kernel was found to be unsuitable in three drying methods in terms of energy efficiency, drying time, and climatic conditions of our region. The higher $\mathrm{L}^{*}$ and $\mathrm{a}^{*}$ values were obtained from fresh plum fruits, whereas the higher $b^{*}$ and chroma values were determined from dried plum in LED light for $4000 \mathrm{~K}$. The hue angle values of dried plum fruits in LED were significantly higher than other fruit samples.

\section{CONFLICT OF INTEREST}

The authors have no conflict of interest.

\section{ABBREVIATIONS}

SSC: Solids soluble content; L*: Lightness; a*: Redness; $\mathbf{b} *$ : Yellowness.

\section{REFERENCES}

1. Luikov AV. Systems of differential equation of heat and mass transfer in capillary porous. Int. Journal of Heat and Mass Transfer. 1975;18(1):1-4.

2. Hawlader MNA, Chou SK, Chua KJ. Development of Design Charts for Tunnel Dryers. Int. J. Energy Research. 1997;21(11):1023-37.

3. Çevik I, Bilişli A. Studies of suitability of some prune varieties for drying. Gıda. 2002;27 (4):285-90.

4. Krokida MK, Karathanos VT, Maroulis ZB, Kouris DM. Drying Kinetics of Some Vegetables. J. Food Engineering. 2003;59(4):391-403.

5. Karaarslan S. Determining of a Drying Model for Microwave Drying of Trabzon Persimmon. Süleyman Demirel University Journal of Agricultural Faculty. 2014;9(1):8-15

6. Mehta S, Soni N, Satpathy G, Gupta RK. Evaluation of nutritional, phytochemical, antioxidant and antibacterial activity of dried plum (Prunus domestica). Journal of Pharmacognosy and Photochemistry. 2014;3(2):166-71.

\section{SUMMARY}

- The Prunus domestica L. fruit that grown naturally in the Black Sea Region was dried using LED technology in a short time with minimum energy and preserving food properties, along with traditional methods.

- Time-dependent drying curves of Prunus domestica L. at five different drying conditions and timedependent changes of the dryer temperature with LED drying were obtained.

- The drying time with 3 different LED temperatures was found to be shorter than that of the drying time of sun drying and electric heater. It was concluded that, energy efficiency was better in LED drying than those of conventional methods.

\section{About Authors}

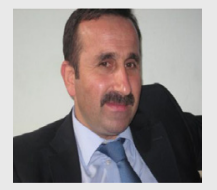

Dr. Mithat Akgün: $\mathrm{He}$ is presently working as assistant professor at the Department of Machine and Metal Technologies in Ordu University. His studies mainly focused on food drying, heat storage and renewable energy sources.

Cite this article: Akgün M, Kandemir L, Öztürk B. Effect of Led Drying on Drying Behavior of Prunus domestica L. Fruit. Indian J of Pharmaceutical Education and Research. 2018;52(4S):S115-S118 